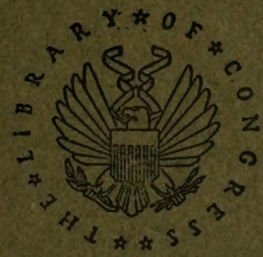

$S$

537

878

1917
Author

Title

Imprint 



\section{Going to College in War Times}

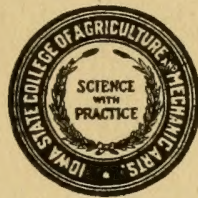

Issued by

IOWA STATE COLLEGE

Ames, Iowa 
D. OP D.

NOV $27 \quad 1917$

$\therefore \vdots$ 


\section{OFFICIAL PUBLICATION OF IOWA STATE COLLEGE OF AGRICULTURE AND MECHANIC ARTS}

\section{Going to College in War Times}

"The number of boys and girls entering college next fall ought to be much larger than usual. In a total of $60,000,000$ people of productive age in the United States, 350,000 students in higher education constitute only about one-half of one per cent. THEIR GOING TO COLLEGE WILL NOT LOWER THE PRODUCTIVE CAPACITY OF THE COUNTRY AS A WHOLE IN ANY APPRECIABLE DEGREE."

U. S. Commissioner of Education Claxion.

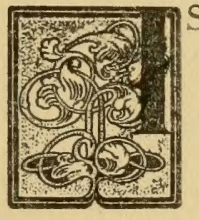

S THIS a year for college or not?

Thousands of young men and women of coilege age and fitness in Iowa, and their parents, are deeply concerned with this question.

For some the answer will come in the call to arms, but for the greater number, by far, the issue of going on with an education or not must be settled otherwise. They must consider what will be the gain or the loss if they do not get that training for big tasks and capable leadership which education affords; they must weigh the needs of the country as well as their own individual ambitions, and then decide. At the same time, they must dispose of the related question, "If not college, then what?" It is demanded of young men and women that they have a positive plan for their lives, not merely a negative policy. It is not enough in these or any other times to be merely cutting off this or that unnecessary thing; it is essential also that there be an adding on of worth-while things and the planning of more and larger undertakings.

Going to college is generally conceded to be worth while. It is so much worth while that it is not to be cut out of the plans of young people without a very urgent reason. It is the world's experience that mainly thru thoro education do men and women qualify for the larger places in life. More and more, those who have had college training are filling the positions of large responsibility and leadership. Ninety-five per cent of those who have

Published weekly. Entered as second-class matter at post office at Ames, Iowa, under act of Aug. 24, 1912. 
achieved things sufficiently important in this country to give them a place in such a list of notables as "Who's Who in America," had the advantages of college education. In many lines of endeavor, and particularly in technical fields, preparation in college is an essential without which it is exceedingly difficult, if not impossible, to win success.

\section{Industry Can Spare Those Ready for College}

BUT a considerable number of young people, or their parents, raise the question whether the war has not changed matters. Granting that thoro education is desirable under the ordinary conditions of peace, they ask whether it is desirable to make sacrifices for it under the extraordinary conditions of war.

Many who ask this question feel that perhaps boys and girls who are ready for college might serve the country better at work in the industries rather than by going to college. They should recall the statement of the United States commissioner of education that if the colleges are filled up this fall they will take out of production only about one-half of one per cent of the men and women of productive capacity in this country, and their going to college will not lower the production of the country in any appreciable degree.

Then, too, there must be considered the relative values of what the boys and girls may do now in the industries and what they may do in a few years with more education and special training for bigger tasks. Without additional education and training they will be part of the many millions who lack these things; with additional education and training they may be counted with the few thousands who have special equipment and who are able to render larger service accordingly. The boy or girl who now abandons plans for going on with an education is quite likely to abandon them for all time, for it will be many times more difficult to go on next year, and perhaps impossible the next. To give up now may mean getting shunted on to some sidetrack of inefficiency, with little or no chance to get back on the main line of efficiency which carries men and women along to bigger aims and ends. Of course it is not unworthy to go into immediate service, but in the long run the young man or woman with education is likely to 
make up many times for the few years spent in college. The United States commissioner of education puts it this way:

"The desire to render immediate service is praiseworthy, but it is effective service which finally counts. Students should ever keep this goal in mind."

\section{War Increases Demand for Educated Leadership}

SOMETIMES the question is asked in this debate about going $S$ to college whether war has not decreased the demand for educated leadership. On the contrary, war has increased it, and will increase it still more. In every field of endeavor, in agriculture, in engineering, in the industries, in the homes, in business, in the professions, in the schools, in public service, in the army and navy, the call is especially urgent for those who have had preparation that enables them to direct and to lead. The organization of the nation's great war machine today is almost wholly in the hands of men and women of college training. Recently a man who knows said that the first shortage of men and women would come in the class of those with special educational qualifications for big tasks. It is certain that the need for such men and women will not grow less as the war goes on, but many times greater, and the war seems likely to go on for years instead of months. From the educational institutions must come a steady, undiminishing stream of skilled doers and capable leaders. Those in authority are as deeply anxious that the schools keep on turning out their product as they are that the farms and mills and mines keep on producing theirs.

For the time after the war there is equal, if not greater, concern. Then a world must be rebuilt and that cannot be done if men and women trained to do it are not at hand. Just what decision young men and women make about going to college this year is of vital importance to the nation. If smaller and smaller numbers are sent out from the colleges in the next few years, the result will be disastrous. Yet that is certain to happen if now there be decision against going to college. No more can something be made from nothing in colleges than elsewhere, and unless their classrooms, laboratories and shops are kept supplied with students, they cannot supply the nation's demands for men trained to do what the nation needs to have done. 
"When the war is over, there will be made upon us such demands for men and women of knowledge and training as have never before come to any country. The colleges of Europe are now almost empty. The older students, graduates and professors are fighting in the trenches or are already dead, as are many scientific and literary men whose work is necessary for the enlargement of cultured life. For many years after the war some of these countries will be unable to support colleges. AMERICA MUST COME TO THE RESCUE."-Secrelary of War Baker.

\section{England's Experience Says “Keep Colleges Filled"}

E NGLAND'S experience gives support to those who believe E that the colleges, and especially the technical colleges, must be kept filled. Her educational institutions were swept empty by the great armyward movement of the first year of the war. Everywhere educational work of the higher sort became disorganized. Great colleges and universities became unproductive and no longer provided fresh supplies of men with special training and equipment for leadership. The nation was confronted with the danger of educational bankruptcy. The error of the policy that depleted the colleges and universities and did not keep up the supply of men and women within them, came home with disastrous results.

Today England is seeking to rehabilitate her educational institutions, particularly for more effective technical and scientific training. She has recently set aside $\$ 25,000,000$ for this purpose, and she is leaving nothing undone to encourage young men and women to fill up the vacant college halls. The English war specialists who came to the United States recently to advise with the president and his cabinet were strong in their representations that to let the colleges be emptied, or even to operate on anything less than at full capacity would be harmful.

In vien of the nation's great need for educated leadership, the presumption is fair that young men and women who are qualified should go to college to fill that need. The burden of proof is on those who doubl the wisdom of going to college this year to prove that any particular young man or poman should not go.

\section{How the Question Must Be Answered} THS question of going to college must, of course, get some-
what different consideration as circumstances vary.

The young man who has been called to the colors for immediate service can make but one reply. 
The young man who is of military age, but whose service is not to begin at once, may feel that the question is settled for him in much the same way and that he should abandon plans for further education. But this is to be said concerning his situation: He may better fit himself for a position of responsibility and larger service in the army or navy while he is in college than out of it, especially if he has already completed one or more years of college work. For him it is the part of wisdom to go on with college, particularly if it be in a technical or scientific institution and if opportunity be given also to take military drill and study military science. There is in sight now a serious shortage of men who are qualified by education and training for leadership in the great army that is under process of organization. Even if he expects to be called in six months from now, the young man in this group will profit if he spends that six months in college, fitting himself for the largest use of his abilities.

The young man who is not of military age, but just out of high school or other preparatory school, will find no better way to prepare himself for the tasks that lie ahead of him than thru college training. He may, of course, render some service in agriculture or the other industries, or in other useful employment, but if he is qualified for college and is ready to make the most of what it offers, his place is there. In the long run he is likely to be of greater service to his country if he goes to college than if he stays out, and his own individual interests will also profit more.

The young woman in college should by all means complete her work; she will face new duties and responsibilities when she comes out and for them she will need every possible bit of preparation. The young woman just ready to enter college likewise should go on with her college education; if ever the home could spare her to fit herself for the greatest possible usefulness, it is in these times that are demanding more of women.

\section{Educators Are Unanimons for Keeping Colleges Filled}

THESE different questions were considered in a meeting of representative educators from 180 colleges and universities with the result that this declaration was unanimously adopted:

"We therefore believe, frist, that all young men below the age of liability to selective draft and those not recommended for special service, who can avail themselves of the opportunities offered by our colleges, should be urged to do so in order that they may be able 
to render the most effective service, both during the full period of the war and in the trying times which will follow its close.

"Students pursuing technical courses, such as medicine, agriculture and engineering, are rendering or are to render, thru the continuance of their training, service more valuable and efficient than if they were to enroll in military or naval service at once."

The United States Bureau of Education at Washington, after careful consultation with the president and those who with him are entrusted with the direction of the nation's affairs in this crisis, recently issued the following suggestions for those who are debating this question of college or no college:

"The number of students in colleges, universities and technical schools should increase rather than diminish. Many of the older and upper classmen will volunteer for some branch of the military service, but all young men below the age of liability to selective draft and those not recommended for special service should be urged to remain and take full advantage of the opportunities offered by the colleges, universities and technical schools, to the end that they may be able to render the most effective service in the later years of the war and the times of need that will follow.

"Practically all pomen students should remain and all boys and girls graduating from high schools should be urged to enter college, technical school or normal school.

"All students should be made to understand that it is their duty to give to their country and to the world the best and fullest possible measure of service, and that both will need more than they will get of that high type of service which only men and pomen of the best education and training can give. Patriotism and the desire to serve humanity may require of these young men and women the exercise of that very high type of self-restraint that will keep them to their tasks of preparation until the time comes when they can render service which cannot be rendered by others.

"No college, university or technical school that can avoid it should permit its faculty or student body to be scattered or its energies to be dissipated. All should redouble their energies and concentrate them on those things that will be of the most service during the progress of the war and which will prepare their students for the most effective service of the country and of the world when the war is over."

\section{IOWA STATE COLLEGE IN WAR TIMES}

A LL that may be said in behalf of going to college takes on special weight when applied to technical education and the work of such institutions as Iowa State College of Agriculture and Mechanic Arts. Its courses in Agriculture, Engineering, 
Home Economics, Industrial Science and Veterinary Medicine link up directly with the country's pressing needs, now during the war, and in the years of rebuilding that will follow. Its training has to do directly with increased production, with conservation, with construction, and with the preparation of men and women for leadership in industrial, technical and scientific fields. This is a time when technical and scientific knowledge and skill are at a premium, and when young men and young women with the kind of education offered in a technical institution like that at Ames will find larger opportunities for useful and profitable service than ever before.

Besides, Iowa State College maintains thoro courses in military drill and tactics, in which young men may qualify themselves for responsible positions in the army, if they are called to that kind of service. Technical training linked with military training fits a student for the greatest usefulness to the nation in war times. The silitary training is thoro enough to qualify students for the examinations for commissions. For the women, lowa State College conducts special Red Cross work, sanctioned by the Red Cross authorities.

In general, Iowa State College has already modified much of its instruction to meet new conditions and when many students were compelled last spring to ask to be excused from college to take up urgent work on the farm or in other lines of production, they were excused on terms that will enable them to make up uncompleted work on a favorable basis. In the coming year such further modifications as to studies and adjustments as to periods of attendance and the making up of work will be made as circumstances may demand. The college appreciates the need of trained men and women in actual service and will co-operate in every possible way to get them into service when they are ready for it.

\section{AGRICULTURE}

THE courses in agriculture at Iowa State College are intended to prepare young men either for the operation and supervision of farms, or for some line of work closely related to agriculture.

Farming itself demands scientific training more than ever, because the farmer of today faces many more difficulties and larger responsibilities than any preceding generation of farmers. He must work with land that is many times as valuable as the land 
his father occuiped, while at the same time it has lost much of its origina tevtity. He must fight new and more destructive insect $r$ sis and plant and live stock diseases. He faces new problems in management and marketing. He must deal with wholly different social and economic conditions. He cannot continue to meet these things successfully except with scientific knowledge linked with practical experience.

Agricultural education also prepares men for a long list of attractive vocations closely related to agriculture. With more vocationa! training in the schools, the demand for teachers of agriculture has become greater than the supply. Increasing agriculturai probiems have increased the work of agricultural experiment station and research laboratories so that many new positions for investicalors have deveioned. The better organization of agricultural interests is calling for a host of county agricultural agents and co-onerative leaders and managers. Business and industry recngnire the need of adapting many of their activities to agricultile and they are calling for men for banks, business houses and a-mies who have the agricultural viewpoint. Journalism is oficring nex npportunities to a limited number of special qualified men with the agricultural viewpoint, while in many other fields the same situation rules.

It is literally beyond the ability of all the agricultural colleges combined to sunply the call for men with their training. In Iowa aione 8.000 new farmers must be recruited every year to replace thare who naturally drop out of farming, to say nothing of hundreds of agriculturally trained men needed for related activities.

Th? courses in agriculture at Iowa State College deal with every phase of the subject:

Animal husbandry

Dairy husbandry

Poultry husbandry

Farm crops

Soils

Dairy manufacturing
Farm management

Horliculture

Forestry

Landscape gardening

Agricultural engineering

Agricultural education and

Agricultural journalism

Every four or five-year collegiate course in agriculture leads to a degree. It includes not only the necessary technical subjects, but ensugh general and scientific instruction to give the student a "ret-rounded education and make of him not only a capable wor:", but also a man abie to take a leading place in his com- 
munity. A two-yaar collegiate course may be elected entitling the student to a certificate.

A decision to enter college for training in agriculture may $\mathrm{nol}$ always be reached now without difficulty, because of the feelins that a boy with interest in farming is needed in productive work on the farm. He is of value there, no doubt, but after all the question is one of relative values and usefulness. Is it more important that a particular boy of marked intelligence and ambition should continue at a hired man's work, or is it more importanl that he be trained to scientific agriculture and leadership so tha! he may in a few years be a supervisor, a manager or a teacher o: investigator in agriculture? If he stays out of college, he will still be a useful man, but will he serve the nation as well as he might with a special education?

Upon this point the United States Bureau of Education recently made this statement:

"In agricultural colleges special intensive courses should be given to prepare teachers, direclors and supervisors of agriculture and practical farm superintendents. It should be remembered that the scientife lenonlcdge and the supervising shill of these men and tinet so: to increase the produclive capacity of thousands of men of less trnoniedge and skill are far more vaiunble than the mols the car as farm hands. The total number of agricultural studenls in all col. leges is oniy a fraction more than one-tenth of one per cent of the total number of persons engaged in agricullure, or aboul thirleen in 10.000 - not enough to affect materially the agricultural prosiction of the country by their labor, but enough to affect it immensely by their directive paver when their college courses have been finished.

\section{ENGINEERING}

ENGINEERING, like agriculture, is close to the big work of the world, both in times of peace and of war, and therefore the courses in engineering at lowa State College have a'waws heen kept close to the practical needs. The instruction offered covers the following general fields:
Agricultural engineering
Architectural engineering
Ceramics
Chemical engineering

Civil engineering

Electrical engineering

Mechanical engineering

Mining engineering 
The courses give the thoro technical training necessary for highgrade professional engineering work and they cover both four and five-year periods. The purely technical subjects receive the necessary emphasis, but enough general instruction is also given to insure the well-balanced development necessary for highest professional success. For its work in engineering Iowa State College has numerous buildings, shops and laboratories, all suitably equipped. There has recently been added a splendid steam and gas laboratory and a new transportation plant and laboratory for instruction in railway and automobile engineering, the only structures of their kind west of the Mississippi.

As in the case of agriculture, the young man who looks toward an engineering career may question whether he should take up or remain in actual production in some industry or take up his education for a higher class of work. To him it may be said that the great need of the country now and in the future is not for men to do the ordinary tasks in the industries, but to supervise and direct big jobs of construction, big shops and factories, railroads and the like. Boys who have looked forward to careers as engineers are certain to find greater opportunities for usefulness if they go ahead with their plans instead of sacrificing them; students who have partly completed courses are not unlikely to render the country greater service by finishing them and thus qualifying for leadership in public or private service.

The need for trained men in engineering is reflected in France's recent call to America for 10,000 skilled engineers. That is but the first of many calls from home and abroad. On his return from Washington, where he made a study of the situation and secured the opinion of leading men, Dean A. Marston of the engineering division of Iowa State College made this statement:

"Our country is facing a great shortage of Dell-trained engineers. We are receiving many times as many calls for men as we can supply. Other schools report the same condition. The war is drawing many engineers into military service. Forcign countries are experiencing even a Dorse shorlage of engineers than the United Stalcs. Many graduate engineers are needed, both to carry on the war and to help build up the industries of the country after the war.

"Presideni Wilson, United Slates Commissioner of Education Claxton, Secretary of $W$ ar Baker and General $W m$. M. Black, chief of engineers, $U$. S. army, urge that high school graduates and others prepared for college ought by all means enter college this fall as a patriotic duty to the country. The situation in enginecring is such that there is a special need for very large freslman classes in the different engineering schools." 


\section{HOME ECONOMICS}

HOME ECONOMICS education has been maintained at I Iowa State College longer than at any other land grant institution. From the beginning it has put emphasis on homemaking and sought to prepare women for complete living, which, Herbert Spencer says, is the function which education has to discharge.

For women, preparation for such complete living must include a study of household administration and management, both private and institutional households; of foods, textiles and other materials and their production and use; of hygiene, sanitation and economics as they concern both home and community; of the care of children and their education; of the social and economic status of women, and of many other things affecting home and community life. These subjects, therefore, are given the principal place in the instruction of women at Ames. If the student expects to live in the country, she may fit herself more fully for her life there by taking some agricultural subjects or by enrolling as a student for a combination course in home economics and agriculture.

Education along such lines takes on especial value in these times of world upset. It will be of equal value in the years following the war when the world seeks to restore itself. "The woman who handles the food supply in the home is equal in importance to the man who handles the gun on the battlefield," writes J. Ogden Armour, food authority. Altho women remain at home in time of national trouble like this, they and the homes they make constitute the real bulwark of national life. Following the war, the call upon women will be greater than ever for a homemaking that will give the nation men and women of strength, character, courage, ability and skill to restore and rebuild a world torn down. Women are, of course, called upon in such times of readjustment as these, to undertake many other labors, but the nation looks to them to do this great work of homemaking first of all, because that is the very foundation of national life.

Outside the home, women trained in home economics will find very broad opportunity in the field of teaching, the demand for thoro home economics exceeding the supply. Extension work, county supervisorships and home demonstratorships in cities are offering new and profitable fields of labor. Playground supervision asks for women with training such as Iowa State College 
gives. Hospitals and other public institutions want dietitians and household managers with home economics training. Municipalities are employing women as inspectors. In the business field home economics graduates are finding openings as managers of cafeterias, tea rooms, hotels, laundries, or as experts in textiles, advisors in home furnishing, and managers or owners of establishments catering to the clothing needs of women and children.

The home economics division at Iowa State College comprises three departments, domestic art, domestic science and physical culture, each offering its own special work. Domestic art includes instruction in textiles and clothing, applied art and the history of art, as they concern the home and its decoration and furnishing. Domestic science includes instruction in foods, hygiene, nutrition and dietetics, household management and training in the teaching of these subjects. The department of physical culture concerns itself, first, with the well-being and correct physical development of the young women of the college, and second, it offers instruction to equip them to teach others.

Four different collegiate courses are offered by the home economics division: A four-year course with emphasis on domestic art; a four-year course with emphasis on domestic science; a fouryear combined course in home economics and agriculture; a fiveyear combined course in home economics and industrial science. Graduate work is also offered in addition.

The technical instruction within the Home Economics division is supported by the work of other divisions of the college. The Industrial Science division provides instruction along general lines and in the foundation sciences. The Agricultural division, thru its department of agricultural education, provides the instruction in the theories and practice of teaching, while other departments offer such courses in agriculture as suit the needs of women. The Engineering division contributes instruction along such architectural and mechanical engineering lines as are of value to a woman in her home work, in the teaching of manual training, or in any other vocation she may choose to follow.

\section{INDUSTRIAL SCIENCE}

COURSES in the Industrial Science division are offered, first, to furnish instruction in the basic sciences that underlie the various industries and professions taught in the other divisions of the college, agriculture, engineering, home economics and veter- 
inary medicine. But they are also offered to give opportunity to the student to become a specialist in some one phase of a science as it applies to industry.

For example, the student may want to become an expert in steel chemistry. He must then give more attention to chemistry than is possible in an engineering course and he gets an opportunity to do that in a specialized course in chemical engineering in the Industrial Science division. The student of agriculture learns something of important insect pests in his agricultural course, but he will find opportunity to fit himself for a specialist in applied entomology without the study along that line offered in the Industrial Science division. Courses in industrial science which lead to a degree are planned, therefore, to allow a student to go further in a science or group of sciences, and still leave him time to take such technical and practical work as will help him to know the application of science to the problems of the industries.

The Industrial Science division offers four-year courses in the following lines:

Major bacteriology
Applied botany
Major botany
Applied chemistry
Chemical engineering
Major chemistry
Major economics
Applied enlomology
Applied geology

In addition to the four-year courses, the Industrial Science division offers in co-operation with the divisions of Agriculture, Engineering, Home Economics and Veterinary Medicine, five and six-year combined courses leading to the degrees of B. S. A. and B. S.: B. S. in Engineering and B. S.; B. S. in H. E. and B. S.; or B. S. and D. V. M.

For those who have had adequate training in any one of these fields, there is a real demand. The various experiment stations, the specialized industries, the federal government, the progressive high schools and the land grant and technical colleges everywhere are demanding scientists, men with fundamental and abundant scientific training, who have had an opportunity to specialize. 


\section{VETERINARY MEDICINE}

VETERINARY medicine has come into a place close to human medicine in social and economic importance. It is no longer concerned solely with the health of domestic animals, important as that work is. Nor is its field now limited to the larger work of safeguarding the meat supply. Today its scope includes also the study of diseases common to both beast and man and the prevention of their spread from one to the other. In the great fight for the protection of public health against tuberculosis, typhoid, parasitic infections and other plagues, veterinary medicine has a notable part. Its methods are scientific and its practice is professional.

New and larger opportunities are continually opening up for veterinarians in private practice, in government service, in experimental work, in educational fields, in municipal health and inspection service, and in the army. Without exception, the graduates find profitable locations in useful service immediately on going out. The scope of the animal industry of the United States, with its investment of more than $\$ 6,000,000,000$, gives assurance that the future of the profession is safe.

Four-year courses leading to the degree of Doctor of Veterinary Medicine are offered. In addition, there are combined sixyear courses with either the division of Industrial Science or the department of animal husbandry, both leading to a B. Sc. and a D. V. M. degree. Each year a special course for practitioners is held.

The instruction is given by five educational departments, each in charge of a man of broad experience in his particular line. These departments are anatomy, pathology and bacteriology, physiology and pharmacology, surgery, and medicine. The college also maintains a department of research in animal diseases and extensive biological laboratories. Students in veterinary medicine are given opportunity to take work in other departments and divisions of the college in order that the course may be well rounded out.

The new buildings at Iowa State College devoted exclusively to veterinary medicine represent an investment of $\$ 200,000$. They rank among the largest and most modern of their kind. Their equipment is complete for instruction in every phase of a veterinarian's work and clinical material is abundant. 
The war has brought a new demand upon the veterinary profession, both at home in increased effort in food conservation and in the army as food inspectors and sanitatians, as well as in the regular veterinary service. Recent legislation has made the veterinarian a commissioned officer in the army, beginning at second lieutenant and rising as high as major. The United States government on the first call sent out, asked for 1,000 veterinarians, or about one-twentieth of the number in the entire country. Other calls are sure to come asking for more. It is evident that the demand will be greater than the supply, not only during the war, but several years after the war. Furthermore, the government has said that it does not want half-trained veterinarians or those who have not yet graduated. Every young man who is inclined toward taking a veterinary course will be doing his patriotic duty by entering college and preparing himself as rapidly as possible for this definite and needed service.

\section{ENTRANCE REQUIREMENTS}

Entrance to Iona State College is based on the standard for the three state educational institutions. Applicants for admission to the freshman class should be at least 16 years of age and they must present at least 15 units of high school work. An entrance unit is defined as 36 weels of high school work in one subject of study, with five class periods per week, each not less than 40 minutes in length; each laboralory period should be at least 85 minutes in length. Of the 15 entrance units, certain are required and the remainder may be elected.

Information concerning the slightly different requirements for admission to the different divisions of the college may be secured by application to The Registrar, on the blank mailing card on inside of back cover, or by letter.

"It is not wise to lose sight of the fact that the country has a fulure as well as a present. . . . The regular work of all our colleges should be maintained with all possible vigor and parents should be encouraged now more than ever to give their children the advantage of a college education."-Editorial, New York Evening Post. 


\section{TWO YEAR SUB-COLLEGIATE COURSES}

For those who are not prepared to enter the regular four or fiveyear collegiale courses, two-year vocational courses are offered in agriculture, engineering and home economics. They are open to young men who are al least 17 years of age, and young women who are at least 18 years of age, who have compleled at least eighth grade work in the public schools, or the equivalent. Graduales of accredited high schools will enroll in the collegiale courses.

In agriculture the studies of farm crops and live stock comprise the foundation and framenork of the two-year course. Around these are poven instruction on other lines of agriculture, and also instruction in such subjects as English, arithmetic and history. There is also a oneyear course in dairying.

In enginecring there are three special lines of instruction:

1. Course for structural draftsmen and building superintendents.

2. Course for mechanical draftsmen and mechanicians.

3. Course for electrical workers and stationary engineers.

A special part time course is also offered to men and boys engaged in telephone work. The first group in this course will begin work in September; the second in January.

The instruction in home economics in the two-year course is planned to meet the very practical needs of young women who want special training in meeting home problems. It does not train them for teaching. Food study, cookery, sening, dressmalking and design take up the greater part of the two years, tho other subjects of domestic and general education are taken up.

Special circulars of information concerning these two-year courses may be secured by addressing The Registrar.

\section{COLLEGE CALENDAR}

For the year 1917-1918, all courses of instruction will begin $W$ ednesday, September 12, at 7:40 a. m.

Prior to the beginning of class work, two days have been set aside for entrance examinations, Thursday and Friday, September 7 and 8.

Registration and classificalion days come on Monday and Tuesday, September 10 and 11. All students are expected to report Thursday. 


\section{USE THIS BLANK}

If you want more complete information about the courses offered at Iowa State College, fill out the blant below.

To the Registrar,

Iowa State College, Ames, Iowa.

Dear Sir:-

I am interested in the instruction offered by Iowa State College, particularly along the line checked below:

\section{COLLEGIATE COURSES}

(Check subject you are interested in.)

Agriculture

Engineering

Home Economics

Industrial Science

Veterinary Medicine

NON-COLLEGIATE COURSES

Agriculture

Home Economics

Engineering

Please send me more complete information about the courses checked. I am not a graduate of a high school. I graduated from the $\ldots \ldots \ldots \ldots \ldots \ldots$ high school.

\section{Very truly yours,}

Name

Address 



\section{LIBRARY OF CONGRESS}

|||||||| || |||||||||||||||||||||||||||||||||| Miniariariantir

\section{물 7834449}

